\title{
Death in the Line of Duty: Caregivers in the Plague narratives
}

\author{
Seema Sinha \\ Research Scholar, BITS Pilani, Rajasthan
}

\begin{abstract}
The dystopian tropes in the plague narratives shift our gaze from the presence of professional ethics to the Gothic horror that unfolds subsequently. Yet whether it is the Great Plague of London in the year 1665, or the Novel Coronavirus in Mumbai in the year 2020, the rampant spread of the contagion and the associated dread bring into focus the selflessness of the caregivers, namely, the medical and the para-medic staff. Comparing the occurrences, one historical, the other still unfolding, this study examines the eery similarities that delineate contagion as metaphor, and the role of doctors in the pandemics. The aim is to find out what happens when the doctors stumble - to succumb to fear, to fall prey to diseases that flesh is subject to, or to violate the oath of Hippocrates. We intend to scrutinize if like soldiers on the battle-front, these frontline warriors also keep their tryst with death in the line of duty, or does History record otherwise. Whether the pestilence be classical or modern, the response of the caregivers is the cornerstone on which any society is grounded. The purpose of this study is to evaluate if courage in the face of disaster is still relevant in this age of anxiety, or does self-preservation win against ethics and morality. A close reading of Daniel Defoe's A Journal of the Plague Year gives us an insight into the timelessness of such issues, especially in a world that is plagued with maladies of its own making.
\end{abstract}

Keywords: Dystopian, tropes, plague narratives, gaze, Gothic, contagion as metaphor

The dystopian tropes in the plague narratives force us to shift our gaze to the Gothic horror that unfolds in the wake. Yet whether it is the Great Plague of London in the year 1665, or the Spanish Flu of 1918, or the novel Coronavirus in Mumbai in the year 2020, the rampant spread of the contagion and the associated dread bring into focus the selflessness of the caregivers, namely, the medical and the para-medic staff. This research paper examines the role of caregivers in the pandemics. The aim is to find out whether the doctors stumble - to succumb to fear, to fall prey to diseases that flesh is subject to, or to violate the oath of Hippocrates. We intend to scrutinize if, like soldiers on the battle-front, these frontline warriors also keep their tryst with death in the line of duty, or does History record otherwise. Whether the pestilence be classical or modern, the response of the caregivers is the cornerstone on which any society is grounded. The purpose of this study is to evaluate if courage in the face of disaster is still relevant in this age of anxiety, or does self-preservation win against ethics and morality. A close reading of Daniel Defoe's A Journal of the Plague Year (1722) and Albert Camus's The Plague (1948) gives us an insight into the timelessness of such issues, especially in a world that is plagued with maladies of its own making.

Contagion as metaphor has driven authors to take conflicting positions. On one hand, the term 'Plague' signifies a curse or chastisement visited from the heavens above, a sanction for the moral depravity that mankind has suffered from since time immemorial. Avarice and the ensuing violence have become the worst diseases that mankind could suffer from, resulting in polluted

(C) AesthetixMS 2020. This Open Access article is published under a Creative Commons Attribution Non-Commercial 4.o International License (http://creativecommons.org/licenses/by-nc/4.o/), which permits non-commercial re-use, distribution, and reproduction in any medium, provided the original work is properly cited. For citation use the DOI. For commercial re-use, please contact editor@rupkatha.com. 
rivers and poisoned air. When "The world is too much with us", as Wordsworth warned, there comes a scourge - to restore equilibrium and reinstate the balance of nature. Just as God's hand causes the visitation, He also stays the blight. His fury spent, the message sent, He gives man a second chance, but, to man's peril, he fails to derive any message from the event.

This was the line of thought practiced by Father Paneloux who proclaimed to the townsmen of Oran: "Calamity has come on you, my brethren, and, my brethren, you deserved it" (Camus, 46). As opposed to this was Dr. Rieux, who did not believe in a God who made His children suffer. Dr. Rieux refused to love the socio-religious order in which the torture of humankind was justified in the name of atonement and expiation. When the young son of Monsieur Othon, the magistrate of Oran, died of the affliction of plague, Dr. Rieux risked being blasphemous and proclaimed that he would prefer saving someone's life and health to salvation (Camus, 106). The trauma and suffering of the plague is evident in the following lines: "The child suddenly doubled up his limbs....the lips parted and from them rose a long, incessant scream .....filling the ward with a fierce, indignant protest, so little childish that it seemed like a collective voice issuing from all the sufferers there"(Camus, 105). Reporting the boy's death, Dr. Rieux said that one could live through such trauma only if one's senses were obfuscated with pain. He regretted that unlike earlier times, his job during the Plague was no longer the routine easing the pain of patients - rather he was now a part of the futile process of seeing, detecting, registering, planning the sick person's evacuation, and ultimately seeing him dead. This pattern was repeated ad nauseum, making the doctor question his own sanity. The gratitude that he had seen earlier in the eyes of his patients was now replaced with suspicion and hatred (Camus, 93). Earlier, he was seen as a protector, but after the advent of plague he was escorted by soldiers who hammered on the door to oust the patient and inter him/her in an isolation ward. His task now was to consign the dying to the hospital, knowing fully well the outcome of the exercise. The placid atmosphere of Oran was disturbed by deaths, initially sporadic, later, a deluge. Dr. Rieux describes the alarming situation in the following words:

When a microbe, after a short intermission, can quadruple in three days' time the volume of the spleen, can swell the mesenteric ganglia to the size of an orange and give them the consistency of gruel, a policy of wait-and-see is, to say the least of it, unwise. Judging by the rapidity with which the disease is spreading, it may well, unless we can stop it, kill off half the town before two months are out. (Camus, 24)

Whether it was the lancing of the putrefied swellings in the groin or the armpits, or dressing the 'fatal stigmata' on the limbs, or closing the eyes of those who ultimately succumbed, Dr. Rieux was there without a care for his own physical safety. The toll that this had taken on his mental health is evident in the following words: "If things go on as they are going," Rieux remarked, "the whole town will be a madhouse" (Camus, 49). The doctor was glad he was exhausted, because "when a man has had only four hours' sleep, he isn't sentimental....he sees the destruction in the garish light of justice - hideous, witless justice...... and the men and women under sentence to death, share his bleak enlightenment" (Camus, 93).

The horrors of plague were reflected in pathetic pleas requesting Dr. Rieux to pity the patient. But he had no time for pity, as he struggled with nerve-racking scenes in the fever-ridden sick-rooms. Families chose to die together than part for being quarantined. So they locked and barred the entrance, followed by forced entry either by the police or by the armed forces. Dr. Rieux recalled the case of Mme Loret, whose daughter was unwell:

Lifting the coverlet and chemise, he gazed in silence at the red blotches on the girl's thighs and stomach, the swollen ganglia. After one glance the mother broke into shrill, 
uncontrollable cries of grief. And every evening mothers wailed thus, with a distraught abstraction, as their eyes fell on those fatal stigmata on limbs and bellies; every evening hands gripped Rieux's arms, and there was a rush of useless words, promises, and tears. (Camus, 44).

All this was made more difficult to bear because of the fact that Dr. Rieux's wife was herself dying in a sanatorium, but as a caregiver his time was sacrosanct and devoted to his patients. That he did at the cost of his own mental and physical health is documented by Camus in his classic work, The Plague. This pattern has been reiterated in several other plague narratives, one example being Daniel Defoe's A Journal of the Plague Year. Defoe reports that the Plague defied all medicines, targeting the caretakers with a vengeance:

The very physicians were seized with it, with their preservatives in their mouths; and men went about prescribing to others and telling them what to do till the tokens were upon them, and they dropped down dead, destroyed by that very enemy they directed others to oppose. This was the case of several physicians, even some of them the most eminent, and of several of the most skilful surgeons. (Defoe, 28)

He further writes:

I think it ought to be recorded to the honour of such men, as well clergy as physicians, surgeons, apothecaries, magistrates, and officers of every kind, as also all useful people who ventured their lives in discharge of their duty, as most certainly all such as stayed did to the last degree; and several of all these kinds did not only venture but lose their lives on that sad occasion. (Defoe, 162)

In his work Agurto Mastix (1665), William Johnson said that in almost every church in London there existed a memorial of physicians who had sacrificed their own lives for alleviating the suffering of their patients (Moote 164). Dr. Nathaniel Hodges described his plague alleviation efforts in his 1666 book Loimologia, where he depicted the unpredictable ways of the malady. He spoke of a 15-year-old girl who had no possibility of surviving the disease, emaciated as she was because of severe malnutrition. Yet she recovered, her buboes 'dissipated by transpiration', her painful swellings subsiding in due course of time. In fact, she 'lost her former distemper, and gathered flesh and strength', giving the doctor credit most deserved (Loimologia 84). In yet another case, a young maid of 16 contracted plague, and though pestilential Buboes came up all over her body and suppurated, he lanced them to help ooze out the poisons and she survived (Loimologia 85). Not everyone was as lucky though. Dr. Hodges records a case where the physical parameters were in order - the patient breathed freely, her pulse was regular, there was no inflammation and she was not in pain - yet when examined closely the tokens of plague were found on her breast, and she died the next day. One can imagine the trauma of Dr. Hodges who, before he had made the discovery of the marks of death on her body, had thought she was 'counterfeiting being sick' (Loimologia 135). Another sexagenarian widow whom he met with at dinner, insisted that she had never felt better. After a hearty repast of mutton and broth, she agreed on getting examined just to humour the doctor, who found 'an abundance of tokens', and by evening she was no more (ibid). When the physicians were pitched against this elusive an enemy, it was natural that they would themselves be in the line of fire, which happened in the case of many. Hodges duly records the sacrifice of his colleagues who fell in the line of duty. He says:

I cannot omit the Mention of those skilful and faithful Surgeons, with due Honour, whose Task in this raging Calamity was very hard and dangerous, how they had the Care of all 
pestilential Tumours and Ulcers, $\mathcal{E}$ c. But although some of these fell themselves in the Discharge of their Duty to others, yet the Survivors went on cheerfully in their Business; and they who lived through the whole, owed a great deal to a Constancy of Mind, as well as to the conservatory Power of Providence. (Loimologia, 205)

In their book titled The great plague: the story of London's most deadly year, A. Lloyd Moote and Dorothy C. Moote bring out the selfless service of Dr. Boghurst who visited homes and interacted with patients, knowing fully well that he was at risk. Like Dr. Hodges, he shared meals with them, sat by their bedside and was present till their dying breath. When even the relatives were gone, it was left to the good doctor to bury the patient as well. "As though immune to disease, Boghurst passed through a multitude of dangers . . . being engaged throughout the day until 10 at night, attending patients in one house after another .....dressing soares and being always in their breath and sweat without catching the disease." (Moote,143). Boghurst says that he was not alone in this selfless service. He appreciated the plague nurses "who were in like danger" (ibid).

If doctors, surgeons, apothecaries and nurses were in the forefront of the fight against the scourge of plague, the other peripheral service-providers were right behind. Defoe documents the efforts of the other professionals who held their ground in the face of disaster, like the clergy, the magistrates, police-officers and other government officials. He lauds the efforts of all those who stayed right up to the end of the blight, ventured out to help stay the course of the disease and laid their lives in the process (A Journal of the Plague Year 190). Defoe says:

I cannot but leave it upon record that the civil officers, such as constables, headboroughs, Lord Mayor's and sheriffs'-men, as also parish officers, whose business it was to take charge of the poor, did their duties in general with as much courage as any, and perhaps with more, because their work was attended with more hazards, and lay more among the poor, who were more subject to be infected, and in the most pitiful plight when they were taken with the infection. It must be added that a great number of them died; indeed, it was scarce possible it should be otherwise. (ibid 191)

Calling plague 'a formidable enemy', Defoe said that it was fortified with horrors that not everyone could struggle against. Some withdrew, but there was a large number of such bravehearts who chose to stay (The Plague 189). Albert Camus brings out the trauma of Monsieur Othon, the magistrate of Oran, who had lost his son. After the tragedy, the magistrate underwent a complete transformation. From a curt, insensitive person, he became the father that he never was. The glint of steel in his eyes gave way to tears as he asked for volunteer work in the plague camp. He pleaded: "It would keep me busy, you see. And also, I know it may sound absurd, but I'd feel less separated from my little boy (The Plague 126)". Human values, earlier overlooked or consigned to the margin, were now brought to the fore. Camus found Casanovas turning faithful overnight, and "sons who had lived beside their mothers hardly giving them a glance fell to picturing with poignant regret each wrinkle in the absent face that memory cast upon the screen" (The Plague 34). People were haunted by the uncertainty that prevailed in the times, and tried to gain whatever control they could have over the volatile situation. The feeling of isolation intensified into the numbness of exile, and the closing of the town gates in Oran emphasized the alienation. The restriction on movement was put in place to control the affliction from spreading, yet the deep sense of estrangement led to anxiety, depression and other mental health issues, adding to the burden of the caregivers.

As the intensity of the plague increased, the duration of forced seclusion also increased. Triantine was scaled up to Quarantine, which again further went up to a Soixantine - from 30 
days, to 40 days to 60 days, and more. While tracing the spread of the blight in London in 1665 the Mootes write:

By the end of 1663, the king's council ordered all ships from Amsterdam to be detained at the mouth of the Thames for a thirty-day Triantine. The civic officials of Rotterdam and London lobbied the privy council to let a perishable cargo of barrelled cod and peas pass through to London for the coming Lenten season. However, a line was drawn: no passengers to stir until Triantine done. In May 1664, the nervous councillors of Charles II extended the Triantine in British ports to forty days, or Quarantine. (The Great Plague, 51)

Defoe also points out:

Where lay the seeds of the infection all this while? Either the distemper did not come immediately by contagion from body to body, or, if it did, then a body may be capable to continue infected without the disease discovering itself many days, nay, weeks together; even not a Quarantine of days only, but Soixantine; not only forty days, but sixty days or longer.( A Journal of the Plague Year, 164)

The disease lay in wait, to spring upon the unsuspecting, just as the freezing of a river did not tame its current forever. It was this volatility of the pandemic that baffled everyone, including the caregivers, who were in the first line of attack. Though the plague did not discriminate, the poor bore its brunt because they could not stock provisions and go into hiding. They had to come out to make a living, or face starvation. Defoe writes that the poor displayed a 'sort of brutal courage', and 'ran into any business which they could get employment in, though it was the most hazardous. He says that such employment included taking care of those debilitated by the malady, working as searchers who identified the cause of death in any given household, or as watchmen who boarded up, marked and guarded the houses afflicted by the disease, as porters who carried the severely ill to the pest-house, or the dead to their graves'( A Journal of the Plague Year, 72).

In many cases, the poor who earlier lived by selling their labour had to consign themselves to the position of beggars surviving on charity. The city subsisted on the largesse of the donors, an account of which was kept by the officials, and proper distribution ensured by the municipal magistrates. "But as such multitudes of those very officers died through whose hands it was distributed", reports Defoe (ibid 75). Amongst the un-organised labour force were the menservants and the maidservants, who were left behind by their masters when the latter retreated into the country. "Had not public charity provided for these poor creatures, whose number was exceeding great, they would have been in the worst condition of any people in the city", says Defoe (ibid 23). The charity as a streamlined effort was also monitored by the Church, with the clergy and the other officials heroically doing their role to alleviate the pain of the poor, at the cost of their own physical well-being.

The poor also suffered because of the unethical behaviour of the profiteers who artificially augmented the prices of the essentials. "The result was that poor families were in great straits, while the rich went short of practically nothing", says Camus (The Plague 115). The rich of Oran continued to enjoy the luxuries that money could buy, whereas the poor in their privation dreamt of moving into the countryside where the air was pure, and the necessities of life were affordable. Since this was not possible because of the closing of the town gates, there was civic unrest, and frequent attempts were made to escape, some of them requiring armed intervention to avoid the spread of the contagion (ibid). The general mood was that of hostility against the caregivers, who 
were struggling with their own challenges which included the proper upkeep of the isolation centres and quarantine depots.

The biggest challenge was the disposal of the dead bodies. The risk of infection, the shortage of coffins and of manpower, i.e. the gravediggers, the stretcher-bearers, the volunteers ultimately led to the doing away with the formalities associated with death and burial. Things came to a head when the indiscriminate tossing in of both men and women in the plague -pits began. The pits were lined with a thick layer of quicklime. "The naked, somewhat contorted bodies were slid off into the pit almost side by side, then covered with a layer of quicklime and another of earth, the latter only a few inches deep, to leave space for subsequent consignments (Camus 86). The dead were buried at night, 'the corpses tipped pell-mell into the pits, and had hardly settled into place when spadesful of quicklime began to sear their faces.... in holes dug steadily deeper as time went on' (ibid 87). When even this was inadequate, 'the denizens of grants in perpetuity were evicted from their graves and had to go to a fiery end (ibid).'

Daniel Defoe describes the process of disposing the plague victims:

They had dug several pits in another ground, when the distemper began to spread in our parish, and especially when the dead-carts began to go about....into these pits they had put perhaps fifty or sixty bodies each; then they made larger holes wherein they buried all that the cart brought in a week....they could not well dig them larger, with water coming on at about seventeen or eighteen feet. (A Journal of the Plague Year 48)

The task of collecting festering bodies, digging graves and burying the dead was left to the poor to undertake, and they were plagued both by hunger and the pestilence.

In her article published in American Literary History (2002), Cynthia J. Davis shares 'writing's infectious qualities, its perilous potency, and contagion and writing as forms of communication'. She draws parallel between a body and a narrative and points out that both can be infested by a succession of "retroviruses". Davis speaks of ideological contaminants, the sources of disease and its cure in metaphor and narrative. While speaking of the spread of HIV AIDS in Africa, Robert Davidson, in his article Illuminating the Art of Medicine, describes a "conversion" party at a Nairobi orphanage, where children born to HIV+ mothers carried the mother's antibodies, and therefore tested positive, although they may not have been infected with the virus. As they cleared the maternal antibodies, they sero-converted to negative status, which was celebrated by the nurses and other caregivers, displaying the resilience of the human spirit. In "Ethics in Times of Plague" Michael Woods Nash says that whenever there is an eruption of a virulent, communicable disease - the caregivers are at grave risk not only for themselves, but also for their families. Exploring the ethical dilemmas that present themselves in plague situations, the author argues that home care may be consistent with the familial ties that the infected person has with the caregiver within the family, but when it comes to health professionals, the dedication and the sense of moral responsibility displayed by them despite the mortal danger is beyond the call of duty, hence laudable.

In her 1826 classic, The Last Man, Mary Shelly brings out the pathos and the trauma of contagion as a narrative device. The autobiographical protagonist is the only one left after a pandemic has swept the world. The pandemic has erased humankind, but for one last survivor who finds himself asking the purpose of going on living in this blighted world. When Mary Shelley lost her children to the contagion, she also lost her will to live. But literature and nature came to her rescue, healing her in the process. Mary Shelley reflects on contagion as a destroyer 
of culture, made ineffective by the will of man to live, or rather thrive, in the face of destruction. Shelley says:

"I also will write a book, I cried - for whom to read? - to whom dedicated? And then with silly flourish (what so capricious and childish as despair?) I wrote,

\section{DEDICATION}

TO THE ILLUSTRIOUS DEAD.

\section{SHADOWS, ARISE, AND READ YOUR FALL!}

\section{BEHOLD THE HISTORY OF THE}

\section{LAST MAN."}

Just as nature revives itself, so does man, who is an intrinsic part of nature. The world has faced disasters of unprecedented scale before, and it will face them in future, but the indomitable will of man will prevail. The courage shown by the caregivers in the pandemics in 1665 in London and in 1940 in Oran, semi-historical narratives both, has amply demonstrated the role of human courage in combatting contagion. Whether it is the case of Dr. Rieux in Camus's classic work The Plague, or Dr. Nathaniel Hodges in Loimologia, or the nameless, faceless 'Chirurgeons' and other support staff in Daniel Defoe's A Journal of the Plague Year, we see contagion being met with courage, and the blight contained by dint of sheer dedication and valour. This is true of any situation, any malady, at any given time. Albert Camus summarizes it for us:

I have realized that we all have plague.......and I know, too, that we must keep endless watch on ourselves lest in a careless moment we breathe in somebody's face and fasten the infection on him....All I maintain is that there are on this earth pestilences and there are victims, and it's up to us, so far as possible, not to join forces with the pestilences.( The Plague 123-24)

The world is once again facing the horror, this time called the corona virus. Doctors and the nursing staff are at the forefront of this battle, and right behind are the support staff - the truckdriver who is on the road transporting essentials when all others are being asked to stay home, the green-grocer who takes extra care in sanitizing the vegetables, the Police-officer who is on his beat to prevent people from spreading the contagion, and when things go wrong, as they routinely do in the times of a pandemic, the pall-bearers, the grave-diggers or the crematorium staff who risk their lives and their family's lives in the line of duty. It is distressing to note the cases of discrimination against the medical staff, who at times have been asked to vacate the house they are residing in for fear of the contagion. As on date when the world has seen 26.6 million cases resulting in 875 thousand deaths because of the Covid -19 pandemic it is easy to lose hope, but history reminds us that we have overcome worst maladies before, and it is just a matter of time that we will overcome this scourge as well, and this would be possible thanks to the frontline warriors - the Corona warriors. It is time we acknowledge the sacrifice of these unsung heroes - the caregivers in this ongoing contagion narrative.

\section{WORKS CITED}

Camus, A. (1948). The Plague. Translated from the French by Stuart Gilbert. Retrieved from http://www.24grammata.com/wpcontent/uploads/2013/o6/The_Plague_Albert_Camus24grammata.com_.pdf 
Davidson, R. (2001). Illuminating the Art of Medicine. AMA Journal of Ethics. https://journalof ethics.amaassn.org/article/modern-plague/2001-07\#

Davis, C.J. (2002). Contagion as Metaphor. American Literary History 14(4), 828-836. https://www.muse.jhu.edu/article/1987

Defoe, D. (1722). A Journal of the Plague Year. London during the last great visitation in 1665 . Retrieved from http://www.pinkmonkey.com/dl/libraryı/digi163.pdf

Hodges, N. [1720 (E-book 2012)] LOIMOLOGIA: An Historical Account of the Plague in London in 1665: With Precautionary Directions against the like Contagion. Retrieved from http://www.gutenberg.org/files/40106/40106-h/40106-h.htm

Moote, A.L.\& Moote, D.C. (2004). The Great Plague: The Story of London's Most Deadly Year. Baltimore, The John Hopkins University Press.

Nash, Michael Woods. (2006). "Ethics in Times of Plague: Home Care, Obligations to Treat, End of Life, and Public Policies. " Master's Thesis, University of Tennessee. https://trace.tennessee.edu/utk_gradthes/1752

Wordsworth, William. https://www.poetryfoundation.org/poems/45564/the-world-is-too-much-with-us 